University of Warwick institutional repository

This paper is made available online in accordance with

publisher policies. Please scroll down to view the document

itself. Please refer to the repository record for this item and our

policy information available from the repository home page for further information.

To see the final version of this paper please visit the publisher's website. Access to the published version may require a subscription.

Author(s): Matthew Watson

Article Title: Planning for a Future of Asset-based Welfare? New Labour, Financialized Economic Agency and the Housing Market

Year of publication: 2009

Link to published version:

http://dx.doi.org/10.1080/02697450902742148

Publisher statement: None 


\title{
Planning for a Future of Asset-Based Welfare? \\ New Labour, Financialized Economic Agency and the Housing Market
}

\author{
Matthew Watson \\ Department of Politics and International Studies \\ University of Warwick
}

Published in Planning, Practice and Research, 24 (1), 2009, 41-56. 


\title{
Planning for a Future of Asset-Based Welfare? \\ New Labour, Financialized Economic Agency \\ and the Housing Market
}

\begin{abstract}
This article focuses on core aspects of the political economy of New Labour and surveys the strategic priorities to which it is likely the planning process will have to adapt. As with other policy areas, the effects of enhanced Treasury micromanagement of the Government's reform agenda has begun to impact upon the field of planning. The prime example in this respect is the Treasury's preference for replacing state provision of welfare-enhancing services with the move towards an individualized system of asset-based welfare. The article begins with an analysis of this shift, showing how it is dependent on creating financialized economic agents who think instinctively as active saver-investors in their quest to accumulate assets to fund future consumption of welfare. In contemporary Britain the housing market dominates the accumulation of assets amongst everyday saver-investors. The article concludes by analysing the possible tension that will be introduced into the planning process because of New Labour's twin goals: (1) to defend the current value of asset wealth even as the mortgage lending market has stalled and confidence in the stability of house prices has temporarily evaporated; and (2) to restrict exclusion from private ownership in the housing market so that broadening access can be used to propel a universal move towards an individualized system of asset-based welfare. The fallout from the world credit crunch which began in the autumn of 2007 and remains ongoing at the time of writing in January 2009 looks likely to exacerbate what was always a tension-prone combination of objectives.
\end{abstract}




\section{Introduction}

The difficulties that befell Britain’s Northern Rock bank in September 2007 revealed both the successes and the fragilities of the political economy of New Labour. ${ }^{1}$ At that time, Northern Rock was the fifth largest mortgage lender in the UK, capitalizing new mortgage debt in the first half of 2007 alone equivalent to roughly $2 \%$ of UK GDP (calculated from www.statistics.gov.uk). Yet, it became the first British bank since the 1970s to activate lender of last resort facilities at the Bank of England as it got caught up in the credit crunch which immobilized inter-bank money market functions over that summer. More notably, it became the first depository institution in Britain since the middle of the nineteenth century to suffer genuine 'run on the bank’ dynamics, as customers withdrew over $£ 2$ billion in private deposits in a critical two-day period over September $14^{\text {th }} / 15^{\text {th }}$ (Observer, 16.09.07).

The most memorable image in the whole episode was the sight of large queues of Northern Rock customers waiting, in increasingly agitated fashion, to close their accounts and withdraw their savings from the bank. Senior Northern Rock officials sought to head off a self-fulfilling panic by blitzing the media with statistics to show that the bank's core business was still highly profitable and that there were consequently no concerns for its solvency. Their argument was that customers were being collectively irrational in seeking individually to reclaim their savings: if they were to leave their money where it was then the bank could continue to function normally without threat to the value of customers' holdings, but by withdrawing their savings customers were eroding the bank’s short-term assets, in turn heightening the potential for a full-blown liquidity crisis and the loss of remaining Northern Rock

\footnotetext{
${ }^{1}$ This piece was written with the financial assistance of a grant from the UK's Economic and Social Research Council (number RES-000-22-2198). I gratefully acknowledge the ESRC's continuing support of my research.
} 
deposits. However, classic run on the bank dynamics are predicated upon collective irrationality arising from individual rationality. Northern Rock customers were prepared to reclaim their savings without thought of the overall cost to the bank, because it was in their interests to secure their assets against any possible future collapse of the bank. Moreover, under the influence of the political economy of New Labour, such actions were largely predictable.

Whilst this is clearly still a process in the making, the Government has made significant inroads into establishing an asset-based system of welfare. The central element of such a system is the reconstitution of the subjectivities of welfare recipients and, by extension, also of economic agents (e.g., Watson, 2008). New Labour has turned the focus away from the passive receipt of state-provided welfare services and towards active management of assets through which individuals become personally responsible for releasing future income streams when welfare needs demand they do so (e.g., HM Treasury, 2006a). It has attempted to instil financialized agents at the heart of its reforms of the British economy, encouraging individuals to think of themselves first and foremost as active saver-investors. The queues of Northern Rock customers seeking to liberate their savings from the effects of banking distress were a vivid manifestation of what can happen when economic agency is successfully reconstituted in financialized form. There was no way of knowing it at the time, but events surrounding Northern Rock have proved to be merely the first manifestation of the increasingly punishing feedback between distress in the mortgage lending and inter-bank credit markets.

The aim of this article is to assess how the ongoing rethink of UK planning practice is likely to fit into a scenario of increasingly financialized economic agency. Will practice be recast so that planning regulations create additional investment 
opportunities for the financialized agent? Or will it seek to protect overall levels of economic activity from the pro-cyclical dynamics of active saver-investor decisionmaking? As much of the process of asset accumulation in contemporary Britain takes place through investments on the housing market, the house price bubble which coincided with New Labour's period of office right up until the credit crunch began in 2007 provides the substantive core of the discussion; the ongoing weakness in credit markets and its associated impact on house prices provides further background commentary.

The article proceeds in three stages. Section one highlights the Labour Government's attempts to actively reframe economic agency in Britain within the context of the move towards an asset-based system of welfare. Section two shows that such a strategy requires the incorporation of financialized individuals into an economy whose growth trajectory is increasingly influenced by asset bubbles. Section three concludes by investigating the implications of inserting planning practice into a system of asset-based welfare, by looking specifically at conditions evident in the British housing market as the price bubble reached its peak. The discussion shows that a financialized approach to housing accentuates many of the social tensions revealed by the pricing trajectory of the bubble, forcing the population into distinct housing classes of 'market-included' and 'market-excluded' in the defence of housing assets already accumulated.

\section{Towards an Asset-Based System of Welfare in Britain}


The idea of asset-based welfare can be traced to philosophical discussions of minimum income guarantees (e.g., Van Parijs, 1992). Policies of this nature arise from contractarian conceptions of justice, in which it is assumed that respect for societal contracts originates from receipt of guaranteed access to the resources that enable life to be led in a dignified manner (Ackerman and Alstott, 1999). This is about manufacturing consent for the prevailing structure of society. The assumption is that society is comprised of instrumentally rational individuals who will accept that it is in their interests for society to function smoothly, so they will support minimum income guarantees that bind all persons to extant social norms for as long as contractarian conditions of justice hold.

New Labour's idea of asset-based welfare departs from such a conception. It too assumes a world of instrumentally rational individuals, but the underlying philosophical framework this time is not so much one of justice as one of duty. More specifically, it is of duty to oneself: to accept responsibility to take care of one's own future consumption needs within the context of increasing state retreat from the arena of welfare provision. The Government has promoted enhanced financial literacy within the population, where the knowledge being imparted focuses on the recognition of future welfare gaps in the absence of corrective action in the present (Froud et al, 2007). This relates particularly to repeated warnings that the value of the state pension will increasingly fall below that which is necessary to preserve the value of consumption possibilities into old age (e.g., HM Treasury, 2001a). Such warnings are encoded with covert moralizing that one is failing oneself if alternative means of protecting future consumption are not activated beyond the sphere of state provision.

The fact is significant in itself that New Labour's asset-based system of welfare comes complete with the need for individuals to reinvent their perception of 
the state/citizen relationship. It represents the outcome of a struggle within Government over the terms on which individuals would be incorporated into such a system (Gamble, 2008). The radical liberal link between asset-based welfare and minimum income guarantees had its supporters within Cabinet but, crucially, these did not include Cabinet ministers with Treasury portfolios. The Treasury view was to use the move to a new welfare model in order to effect a significant process of agential change within the British economy (see also Sherraden, 2005). The Treasury view won out, ensuring that a much more conservative policy duly arose. It emphasized the desirability of a self-sufficient citizenry at one stage removed from direct receipt of state-sponsored welfare services.

The proffered solution begins with the individual accepting the responsibility to work and the further responsibility to divide the rewards from work between current consumption and saving for the future. The more substantive element of the Government's financial literacy drive has been oriented towards making people aware of the investment vehicles through which they might be able to multiply the value of their savings. The intention is to continue to harbour an instrumentally rational approach to individuals' financial planning, but at the same time to change their aspirations from being cash-rich to being asset-rich. The greater the performance of the asset the more that future consumption possibilities can be expanded by its ownership. A person who is fully attuned to life lived within an asset-based system of welfare is someone who will build up a portfolio of assets out of current savings so that foregone consumption possibilities in the present can be translated into future consumption of welfare-enhancing services. Such people are said to be smoothing their consumption over the life-cycle, abstaining in part from consumption when income is at its highest but the demand for welfare is not, in order to expand 
consumption at the point of the life-cycle when these features are reversed. Assets are therefore to be treated as if they were stored-up labour: they provide income but break the contiguous temporality of the usual relationship between income and work.

In its original form, as an element of philosophical discussions of minimum income guarantees, the idea of asset-based welfare contains an important element of economic egalitarianism (Finlayson, 2008). This is an egalitarianism which emphasizes equality of outcome, and the state is used to institutionalize the redistributive instruments which enable everyone to receive a minimum income irrespective of their current earnings capacity on the labour market. A relationship between the individual and the state is thus invoked whereby the individual enjoys a level of income guaranteed by the state solely as a condition of citizenship.

The Government's chosen system of asset-based welfare also has an aspect of economic egalitarianism to it, but in substantive terms it differs markedly from what has been outlined above. For a start, its egalitarianism is not predicated upon equality of outcome so much as equality of opportunity. The Government has shied away both from promises of unconditional access to state-sponsored income and from the very idea that there is anything inherently desirable about ensuring equal shares of income (e.g., Coates, 2005). It acknowledges that an asset-based system of welfare revolves significantly around the depth of savings within society, and it limits its egalitarianism to providing the conditions in which equal access to developing the savings habit prevails (HM Treasury, 2001b). Differential ability to finance savings out of current income is not a justification for redistributive interventions by the state, and neither is accelerating disparities in asset-ownership or in the likelihood of being able to engage in future welfare-enhancing consumption. For New Labour, the sole task of the state 
in this area is to ensure that all individuals, and especially those from poorer families, are able to act upon the imperative of becoming a regular saver.

Such a stance departs quite significantly from the relationship between the individual and the state implied by minimum income guarantees. Under the terms of that proposal, the individual only needs to be a citizen to qualify for state support: nothing is required in any genuinely active sense to justify continued receipt of that support. For New Labour, by contrast, action is everything. Individuals who are to be helped by the state to develop a portfolio of assets have first to demonstrate through observable behaviour that they are trying to immerse themselves in the savings culture (e.g., HM Treasury, 2007). Citizenship carries no automatic entitlement to state support and, on its own, it counts for nothing in this instance. Individuals have to mould themselves instead to prescribed courses of action consistent with what the Government expects them to do to help themselves. The ideal that they should be seeking to emulate is people who embrace the savings habit as an everyday act, who think of savings as the route to investment, and who invest to secure their long-term welfare. Acting in this way, everyday life is reduced to an ongoing series of financial decisions and the individual emerges out of that life as a financialized agent. The following section focuses on New Labour's attempts to facilitate an economy full of financialized agents suited to the move towards an assetbased system of welfare.

\section{Towards Financialized Agents in Britain}


The financialization of everyday life occurs when active saver-investor characteristics displace other sources of economic identity (e.g., Martin, 2002). With respect to contemporary Britain, this is clearly a tendency in the making, containing multiple sites of resistance, rather than a process that has already become fully embedded. It involves exposing current social standing as a consumer as well as future aspirations for material provisioning to the pricing dynamics of asset markets. The calculations associated with how to live everyday life thus come to mimic those of professional investors: how to treat life itself as a series of investment decisions; how to position the household's assets on the right side of pricing trends; and how to plan for the long term by being able to continually trade-up the value of assets (see Langley, 2008).

If this sketch appears to capture the essence of more and more people's everyday economic experiences, then the very familiarity of active saver-investor status does not necessarily imply a benign process. To invoke a Foucauldian image, financialization acts as a moral technology of control. It depicts an ostensible logic of choice, as it remains a matter for the individual of whether or not to build up a portfolio of assets, but the actual choice involved is very one-sided.

The flipside of the financialization of everyday life - and, in many ways, its cause - is the gradual withdrawal of state insurance of future income. From beginnings as a strictly marginal activity perceived to be of no social worth, insurance itself has increasingly been 'moralized' (see de Goede, 2004) - i.e., it has been socially instituted as a necessity of responsible individual activity in a world of heightened risk and uncertainty. To be insured is to adapt oneself with good sense to one's surroundings, whereas to consciously remain uninsured is an act of recklessness which fails the moral test of prudent management of the self. In a context of gradual withdrawal of state insurance of future income, anyone who does not secure their 
future income by providing themselves with the private insurance of a portfolio of performing assets faces social disapprobation for their inaction. The choice facing the individual under conditions of financialization is therefore between, on the one hand, conforming to the financialization trend by accepting that asset-ownership is merely a form of private insurance of future income and, on the other hand, leaving future welfare needs uncovered and inviting moral condemnation for doing so. In such circumstances it is hardly surprising if most people with sufficient money to become active saver-investors opt to reconstitute their economic identities in line with the financialization trend, even if this involves submitting themselves to a dynamic which is, at heart, deeply coercive.

In contemporary Britain, the financialization of the economic agent tends to be based on two substantive processes, one of which involves a changing relationship between the individual and the provision of pensions and the other a changing relationship between society and the housing market. The former is a contextual factor promoting a new understanding of economic subjectivity, whilst the latter is a behavioural factor enabling the manifestation of active saver-investor characteristics.

Taking them in turn, immediately on coming to office New Labour attempted to construct a moral platform for welfare reform based on a new political discourse of individuated responsible citizenry. The aim in this respect has been to approach many of the ends of the previous Conservative Governments, but to use more subtle means. Its predecessors were content to adopt directly the language of markets and of taxpayer revolts in order to articulate ways of reducing the fiscal burden of stateprovided welfare. Given its party history, such language is not as readily available to New Labour. Instead, it has emphasized the necessity for individuals to take out adequate insurance to meet their future welfare needs and to sensitize them to the 
responsibilities they owe to themselves for doing so. The reality of insured individuals automatically draws them towards market relationships, but by focusing on the politics of responsibility in the act of taking out insurance the language of markets is not required to sustain the process.

Consider the Myners Report on future pension provision, commissioned by the Brown Treasury and reporting directly to it (HM Treasury, 2001a). It made headlines for its blunt assessment that the current trajectory of state-provided pensions is unsustainable. Yet, whilst this was undoubtedly the main story that the Report had to impart, for current purposes the manner in which the telling of the story was framed is just as important. The primary encoding devices in use were: (1) the image of an autonomous individual with choices to make about how best to confront the challenges of everyday life; (2) the related image of an uncertain future - what Anthony Giddens (1991: 7-10) generically has called ‘ontological insecurity’ - which requires the individual to be forward-thinking and to coordinate lifetime income flows to meeting future eventualities; (3) the assertion of the moral propriety of insurance as a social technology designed to counteract the tendency towards ontological security; and (4) the use of doomsday forecasting to shift the burden of pension responsibility from the state to the individual. The Myners Report is liberally inflected with the social ideology of financialization, and it should be viewed in its own right as an important part of the trend towards financialized economic agency in New Labour's Britain.

Whenever state retreat in pension provision is foreshadowed, it is accompanied by the expressed opinion that the prudent person would in any case be building up an asset base to provide the ontological security of known future income streams, whether the factor of state retreat is evident or not. That injunction plays up 
to what Gordon Brown (2006) has referred to, in complimentary terms, as the "new individualism of rising aspirations”. The argument is this: that even were the current value of the state pension to be defended forever, it is both right and commendable for every generation to want to enjoy a greater level of material comfort in old age than its predecessors; therefore, the state pension can never be enough on its own to satisfy continually rising expectations. New Labour has thus implored everyone to turn their attention to enhancing asset ownership. Perhaps unsurprisingly, given that around $40 \%$ of aggregate accumulated wealth in Britain is already concentrated in owning the family home (HM Treasury, 2000: 4), the housing market has become the lynchpin of this process.

Public housing formed one element of state insurance of future income within the post-war British welfare state (e.g., Ford and Wilcox, 1998). Those who were able to satisfy their own housing needs through private markets were compensated in other ways for helping to maintain the fiscal basis of a public housing system on which they had no call. In particular, this came in the form of significant mortgage interest tax relief, which pushed the effective cost of owner-occupation well below the market rate (Malpass, 1996). This dual system of housing subsidization channelled individuals into distinct housing classes for much of the post-war period, whereby existing social stratification provided people with a route into a particular housing class and the process of being embedded within a particular housing class served further to institutionalize the social stratification (e.g., Wilding, 1997). There was a marked absence of mobility between the two housing classes, because both were dependent for their tenure on incorporation into a state-provided system of welfare (e.g., Cronin, 2004). 
The move under New Labour to state retreat in pension provision and towards an asset-based system of welfare would clearly have unsettled this relationship had it still existed, but the reframing of the idea of housing rights in the 1980s had in any case brought about its demise. Within the context of the post-war British welfare state, housing was treated as a merit good. As such, it was assumed that everyone had a right to affordable housing and that it was the responsibility of the state to ensure that this right could be satisfied. However, the politics of the 1980s challenged the notion of housing as a merit good and strove to replace it with the notion of housing as a private investment vehicle. Echoing this shift, the right to housing as a universal commitment to individuals for living life within society was transformed into the right to make money out of successful trading up on the housing market. This also changed the role of the state from direct securing of distinct patterns of housing tenure to securing a macroeconomic environment in which mortgage lending conditions produce continual upward pressure on house prices (e.g., Watson, 2008).

The stability culture championed by New Labour has had notable success in achieving this aim, with house prices increasing pretty much continuously in Britain throughout the Government's first ten years in power. This has been accompanied by the rise in popular culture of 'home improvement', where the underlying rationale is to demonstrate how every last penny of value can be wrung out of a house. Taken together, these trends have changed how many people view their homes. No longer is the instinctive reaction necessarily that the home is the arena for nurturing family relationships in a fundamentally private forum. Instead, it is just as likely that the home will be viewed as a quasi-public space, at least insofar as it is merely one component of the housing market. Under the influence of financialized agency, the home is only ever one decision away from being placed on the open market, and 
consequently it is desired equally as much for its potential as a high performance asset as for being the space for living family life.

The article concludes by considering the implications for planning of the increasing tendency to view the privately-owned family home through the perspective of financialized economic subjectivities. It also reviews how those implications have changed to reflect the Government's changing priorities for the housing market in the wake of the credit crunch beginning in 2007 and the subsequent record-breaking oneyear fall in house prices in 2008.

\section{UK Planning in the Context of the Financialization of Everyday Life}

From its earliest days in office, New Labour has declared its interest in 'joined-up government' (Clark, 2002). Its stated desire in this respect has been to move away from making policies on a one-by-one basis, for fear that the introduction of one such policy might change the context in which another policy operates so decisively that it undermines any chance of that policy being successful. Instead, coordination across policy areas has been the goal, requiring the thought process to be oriented towards a complete package of reforms rather than in terms of individual policies (e.g., Bogdanor, 2005). This makes it likely that planning practice will be considered relative to the general thrust of policy, rather than as a case on its own.

The institutional mechanism through which this change in policy-making style has been facilitated is the increasing scope of the Treasury to intervene in the activities of other government departments. The more that the Treasury has been allowed to extend its reach, the more that the policy-making process as a whole takes 
on the appearance of a single web with the Treasury at its centre (e.g., Buller and Flinders, 2005). The outcome might well be more consistency across different policy outputs, but it is also likely that all policies will be inflected with a clear stamp of Treasury preference. As the tendencies towards an asset-based system of welfare and towards financialized economic subjectivities both have their origins in Treasury policy, they are increasingly likely to be the standard against which other policies are judged for their viability. Purely from a policy-making perspective, then, a likely scenario for future planning practice is one in which it is not only consistent with the move towards an asset-based system of welfare and the financialization of everyday life, but also serves to add extra gusto to it.

Interview evidence gathered from some of those who were close to the process does indeed suggest that the Barker Review of Land Use Planning was both Treasuryinspired and Treasury-led (personal correspondence with Andrew Inch). The Review contained a substantial commentary on the housing market (HM Treasury, 2006b), which in turn built upon an even lengthier treatment in the Barker Review of Housing Supply (HM Treasury, 2004). Taken together, the two reviews do nothing to decisively refute the suggestion that New Labour deliberately manipulated the house price bubble which coincided with its first ten years in office. Certainly, the Treasury's preference for using the housing market as a means of social reform remains intact as a result of the recommendations of the final reports.

A survey at the end of December 2008 by the Nationwide building society showed that the average house price in the UK was $£ 153,000$ (BBC News, 06.01.09). This was down from the October 2007 peak of $£ 182,000$, which itself represented the culmination of an average annual rise of $12 \%$ between 1997 and 2007 . As a consequence of such increases, for the proportion of the population who have been 
able to turn savings into assets, the home is now most people's prime asset. The house price trajectory of its first decade in office provided New Labour with its main means of incorporating individuals into an asset-based system of welfare and from there of warding off political mobilization for other forms of welfare provision. The whole of the Government's macroeconomic agenda - 'sound money’, 'credibility', 'business first' - would begin to look increasingly fragile if concerted pressure were brought to bear through the political process for renewed effort towards direct state provision of welfare.

However, it is important not to run too far ahead of the argument, because events have subsequently intervened to force at least a partial rethink onto Government priorities for the housing market. The foregoing continues to capture the overall logic of the Government's approach, but a comparison between before and after the credit crunch becomes instructive. The baseline for the comparison is the autumn of 2007, when the first signs emerged that the banking sector distress arising from the fallout of that summer's world credit crunch would feed through into housing market distress in the UK.

Throughout 2008, the Government was able to find massive amounts of public money to enact interventions designed to pre-empt and therefore to militate against the worst effects of impending recession. Almost without exception these interventions contravened its previously stipulated 'golden rules' for keeping its macroeconomic agenda on course. At the time of writing it is still too early to say whether this amounts to a decisive change of direction, but there are reasons for thinking that this is unlikely to be the case - not the least of which being the Government's own insistence that its interventions are temporary measures until normal order is restored in the economy (BBC News, 19.12.08). For the purposes of 
my argument, moreover, it is worthwhile noting that changes to the tax system have not been linked with the return to old-style public welfare provision. They have been used simply as stimuli for levels of consumption activity which might enable the real economy to remain buoyant and to remain an arena in which asset accumulation is a viable expectation.

New Labour's long-term priority for the housing market before the onset of the credit crunch had been asset accumulation designed to drive the move towards a system of asset-based welfare, and its emergency economic measures introduced throughout 2008 do not appear to undermine that priority. Issues of affordability and the need to balance asset accumulation with ensuring access for new participants in the housing market were being discussed by planners before the onset of the credit crunch but elicited no sustained public comment by the Government. Since the autumn of 2007, though, the long-term priority has also been conjoined with explicit Government recognition of the competing short-term priority of improving homeownership affordability as a means of withstanding the potential for an outright market collapse. This has been designed in order to maintain the inflow of buyers necessary to prevent the mortgage lending market from temporarily seizing up and therefore to prevent even larger falls in house prices than currently predicted from spilling over into a deeper recession in the real economy. Mortgage providers reacted to the revelations about subprime lending by tightening the terms on which mortgages were made available in an attempt to prove that their business was built on solid foundations. Yet, the scaling back of loan-to-value ratio forced many potential homebuyers out of the mortgage lending market and further depressed prices as a consequence. 
The long-term strategy requires continual increases in house prices so that mortgage debt can be more than counter-balanced by higher levels of housing market wealth. The short-term strategy was initially enacted when the first reports came out from the UK Council of Mortgage Lenders predicting a plateau in house prices at their 2007 level for the whole of 2008 (BBC News, 11.12.07). But since then the predictions have become much more pessimistic. By June 2008, HBOS, the UK's largest mortgage lender, predicted that the overall value of the housing market would fall by $9 \%$ in 2008 and for it to take up to four years for house price growth to kick in again (BBC News, 19.06.07). The same report estimated that the volume of UK mortgage transactions in 2008 would be down $45 \%$ from twelve months previously, which seemed set to accentuate the downward pressure on prices still further. Subsequent events proved even these revised estimates to be too optimistic. At the time of writing the most up-to-date figures are for the end of 2008. These showed an annual fall of $15.9 \%$ for average house prices (or 18\% from the October 2007 peak), and an annual fall of over $60 \%$ in the volume of mortgage lending (BBC News, 06.01.09). The balance between the Government's long-term and short-term housing market priorities has become more pronounced in favour of the latter the more that it has been faced with increasingly gloomy predictions about the likely pricing trend.

The planning process is now being inserted into a political context in which the new emphasis is on avoiding an affordability crisis in the interests of inserting price floors into a falling market. Yet, in effect this is merely to shut the stable door after the horse has bolted. It is true that affordability statistics continue to make for sobering reading, but it would be wrong to attribute them to the impact of the credit crunch and the associated perception of individuals feeling less well off. Moreover, it would also be wrong to assume that planning practice alone can cure current 
affordability problems. Those problems have long-term roots which relate to the gradual eclipse over thirty years and more of a cultural politics of housing which treated the guarantee of access to housing as a social right (Schwartz and Seabrooke, 2008). The shift to viewing housing as an investment good has had a noticeable impact on the amount and type of financing available for building houses. Private financial institutions have concentrated on making increasing amounts of commercial credit available to the private market, whilst the government has systematically withdrawn state credit from public housing. The numbers collapse in new homes is almost solely a public housing phenomenon, and the affordability figures currently reflect the imbalance between private and public housing (National Housing and Planning Advice Unit, 2007). Correcting that imbalance is not in the gift of planners, because it is linked to changes in the cultural politics of housing and, in turn, to broader social changes enacted since the 1970s.

The proportion of take-home pay required to service mortgage repayments the measure traditionally used to assess housing market 'affordability' - has increased rapidly from a figure of just over $25 \%$ in 2003 , where it had been more or less continuously for the previous decade, to one of $42 \%$ at the peak of the house price bubble in 2007 . The only other time it has breeched the $40 \%$ barrier was for the period between 1990 and 1992 during the collapse of the previous UK housing market bubble (Royal Institution of Chartered Surveyors, 2007). That collapse precipitated an economic recession which hit homeowners particularly hard (Taylor and Bradley, 1994). The proportion of take-home pay required to cover the up-front costs associated with house purchases - the measure of housing market 'inaccessibility' has risen even more dramatically than the affordability figure which concentrates on mortgage repayments. This peaked at just under $60 \%$ during the house price bubble 
of the 1980 s, fell steadily to around $20 \%$ by the time New Labour came to power in 1997, but topped 100\% for the first time in 2004 and hovered around that figure for the duration of the most recent bubble (Royal Institution of Chartered Surveyors, 2007).

A functioning asset-based system of welfare can be expected to survive for the long term only if continual access into it is guaranteed from one generation to the next. Yet, recent figures for housing market affordability and accessibility are strongly suggestive of the possibility that distinct housing classes of 'marketincluded' and 'market-excluded' have been institutionalized in the defence of previously accumulated housing assets. We can already see evidence of clear distributional tensions between those who have secured access into the system of asset-based welfare via the housing market and those seeking such access. The former group have an interest in the Government continuing to press ahead with its unchecked long-term strategy for housing market asset accumulation and the associated encouragement of bubble dynamics in house prices. By contrast, the latter group have an interest in the Government emphasizing the short-term strategy for improving homeownership affordability and the associated encouragement of price stability. The route to protecting the gains already made in the move towards an asset-based system of welfare passes through the interests of the market-included. However, avoiding a more dramatic collapse in house prices on the back of the falls from autumn 2007 to the time of writing currently looks as though it entails prioritizing the interests of the market-excluded.

New Labour could now find itself on the horns of a dilemma, where the longterm and short-term needs of the agential change it wishes to impose on the British economy require very different types of intervention into the housing market. This is 
something that it has acknowledged for some time, making the identification of the credit crunch of summer 2007 in one sense a bit of a false benchmark. What is different today, however, is the explicit emphasis which is placed on affordability issues in a bid to bolster flagging prices. This has given it a prominence in public debates which it has not previously enjoyed. Yet, the tension on which it is built how to maintain existing asset values concentrated in homeownership whilst nurturing the expectation that the experience of homeownership could be made available to all has a longer-standing place in the Party's thinking. Indeed, the stated premise of the Barker Review of Housing Supply (HM Treasury, 2004) was how best to make planning for housing more sensitive to spatial concentrations of demand as a way of avoiding exclusionary pricing dynamics.

The Government has recognized that the next generation of aspiring assetholders will be excluded from accumulation dynamics on the housing market unless affordable housing becomes more widely available (HM Treasury, 2006a). It continues to use the language of inclusion when talking about its hopes for the housing market's future. In this way it presents itself as defending the drive for 'aspiration' and its spread throughout society. The Government's recent turn towards concerns for affordability suggests that it is not prepared to knowingly frustrate the interests of the market-excluded by simply following the interests of the marketincluded. However, question marks remain about what it can do to correct the ongoing imbalance between private and public housing even if it is of a mind to intervene along such lines (and this is currently a big 'if'). Interventions consciously promoted as intended to make housing more affordable serve only to raise the prospects of political unpopularity as those with assets accumulated in the housing market look to the government to help them maximize their gains. 
New Labour's attempts to balance potentially incompatible long-term and short-term priorities have led to an increasingly ad hoc approach to housing market matters. There are definitely moves in Government circles away from the desire to embed an extreme version of a fully financialized future for those who have already secured access onto the housing market. This allows for the needs of the current market-excluded to be recognized. Yvette Cooper, Minister of State for Housing and Planning in the Department for Communities and Local Government, announced in September 2007 a crackdown on the 'empty home plots' phenomenon (Financial Times, 13.09.07). Property developers have shown themselves to be more than willing to play the housing market to their own advantage, by winning planning permission but then hoarding empty building plots to increase the value of their other developments in nearby locations. This clearly intensifies both supply constraints and the upward trajectory of prices in the context of bubble dynamics, but it also intensifies affordability constraints. In this instance, the Government backed the cause of the housing market-excluded rather than treating the bubble as the exclusive goal of policy, and this took place even before the fallout of the world credit crunch began to distress the housing market. The suggestion remains, though, that this was nothing more than a one-off intervention designed to quell a specific concern being voiced by the media rather than an element of a fully operational programme for restructuring the housing market in line with the needs of the market-excluded.

The evidence against this forming part of a fully operational programme comes in the Government's continued tolerance of the effects of the 'buy-to-let' sector, even when those effects work in the opposite direction to other aspects of its housing market policy and when they can be shown to have been a powerful propelling force for the recent house price bubble. Very soon after Cooper struck out 
against the empty home plots phenomenon, specialist builders in city centre developments reported to the stock market plans to mothball until further notice already acquired city centre sites (Guardian, 18.11.07). The difficulties experienced by most banks in the aftermath of the credit crunch in the summer of 2007 led to a retrenchment of their mortgage lending business, a contraction of demand by borrowers seeking to invest in the buy-to-let sector, increased problems for developers trying to sell new properties in that sector and an increased reluctance to begin the next phase of their developments whilst existing stock remained unsold. The whole buy-to-let dynamic has proved to be something of a double-edged sword for the Government's broader trajectory of reform. It provides an ideal route for many already market-included families to expand their asset base through purchasing a second property. Yet, the effect of the buy-to-let sector in increasing housing demand at a higher rate than housing supply has led to price dynamics which have ratcheted up affordability problems and left many potential first-time buyers without access to asset accumulation via the housing market.

Although the Government has sat on its hands in relation to the buy-to-let sector, it has shown a more interventionist side in tackling one aspect of housing market exclusion through the Key Worker Living programme (Department for Communities and Local Government, 2006). This has been designed to ensure that people employed in frontline public service delivery - especially in the areas of healthcare and education - are not put off remaining in that employment because their salaries act as a barrier to entry onto the housing market. Direct subsidization of property purchases by key workers - at the time of writing to the tune of nearly $£ 334$ billion - has been encouraged in order to keep them in their jobs. As yet, though, there has been no attempt to extend this programme to a general principle in order to 
induce a more socially inclusive accumulation of housing market assets across the market-excluded population as a whole. Whilst doing so would clearly widen the scope of asset accumulation amongst the population, doing so specifically through broad-based intervention in the housing market might begin to devalue other people's assets already accumulated there.

New Labour might continue to insist that there is no 'either/or' choice to be made in this respect, but its own increasingly ad hoc approach to policy appears to undermine the claim. What emerges is an increasingly patchwork approach to housing market policy which lacks a coherent central thread in terms of a single underlying organizational principle. It is such an approach into which the planning process now has to be incorporated, and the lack of internal coherence threatens to impose a similar standard onto planning.

\section{Conclusion}

It is, of course, too early to draw definitive conclusions about the impact on UK planning of: (1) the Barker Reviews; (2) the broader trend towards the financialization of everyday life which forms the backdrop to the Reviews; and (3) the fallout from the world credit crunch which, for the time being at least, has temporarily appeared to alter the Government's priorities surrounding the financialization trend. In many ways, though, the current article is not about conclusions, so much as identifying important contextual factors that will have an effect on UK planning in the future. Given its significance for so many aspects of the British economy, the housing market will continue to form a crucial part of the backdrop to the planning process, and for 
some time to come the important contextual factors for the housing market will be the three identified at the start of this paragraph.

As the recent Northern Rock bank run demonstrates only too clearly, large sections of the British population now recognize the move towards an asset-based system of welfare as an integral part of their everyday life. No amount of carefully scripted Government assurances or eminent economic opinion was sufficient to prevent mass deposit withdrawals because the perception had taken hold that privately-owned assets, in the form of individual savings, were at risk. Those Northern Rock investors who chose to liquidate their remaining savings in the bank did so precisely because they took seriously New Labour's constant reiteration of the plea for individuals to accumulate their own personal portfolio of assets.

It is surely more than coincidence that this event centred on one of the mainstays of Britain's mortgage lending business, because the housing market is now an essential ingredient of the move towards an asset-based system of welfare. Yet, the accompanying financialization trend threatens to intensify social contradictions that were already evident in the pricing trajectory of the housing market. What we do not know yet is the extent to which planning practice will be required to manage the negative externalities arising from the financialization process in terms of the distributional tensions between the housing market-excluded and the market-included. Uneven access to asset bubbles creates new forms of social stratification, thus introducing potential political sites of conflict within the existing economic order. In addition, asset bubbles inflate in a clearly pro-cyclical manner and when they burst as is presumably happening at the moment - they have a tendency to drag the whole of the economy down with them. The current distress of the British retail sector and the move into administration of many of the country's best-known firms - 
Woolworths, Wedgwood, MFI, Zavvi, etc. - appears to exemplify such a trend. We also do not know the extent to which planning practice will be required to deal with the wholly novel negative externalities arising from a dramatically falling housing market in the context of broader financialization dynamics.

Planning practice on its own cannot resolve these issues, although it might nonetheless be called on as part of a tidying-up operation in the event of clear fractures opening up in housing market policy. This is not likely to be something for the planning profession to celebrate. The housing market cannot be used to propel a universal move towards a system of asset-based welfare in the context of deep-seated exclusion from it. But neither is popular legitimacy for the Government's broader financialization strategy likely to be maintained if the Government intervenes to deliberately lessen affordability constraints in the context of already falling house prices, knowing that this will destroy wealth already accumulated in homeownership. The increasingly ad hoc nature of New Labour's housing market policy provides evidence that the tensions in its approach are already beginning to bite, and planning practice is likely to be embroiled in the fallout.

\section{References}

Ackerman, Bruce and Alstott, Anne (1999) The Stakeholder Society (New Haven, Yale University Press).

Bogdanor, Vernon (Ed) (2005) Joined-Up Government (Oxford, Oxford University Press). 
Brown, Gordon (2006) The Donald Dewar Memorial Lecture, Speech delivered at the University of Glasgow, October $12^{\text {th }} 2006$.

Buller, Jim and Flinders, Matthew (2005) The domestic origins of depoliticisation in the area of British economic policy, British Journal of Politics and International Relations, 7 (4), pp.526-544.

Coates, David (2005) Prolonged Labour: The Slow Birth of New Labour Britain (Basingstoke, Palgrave Macmillan).

Clark, Tim (2002) New Labour’s big idea: Joined-up government, Social Policy and Society, 1 (2), pp.107-117.

Cronin, James (2004) New Labour's Pasts: The Labour Party and Its Discontents (Harlow, Pearson).

de Goede, Marieke (2004) Repoliticizing financial risk, Economy and Society, 33 (2), pp.197-217.

Department for Communities and Local Government (2006) Evaluation of Key Worker Living: Final Report (London, HMSO).

Finlayson, Alan (2008) Characterizing New Labour: The case of the Child Trust Fund, Public Administration, 86 (1), pp.95-110.

Ford, Janet and Wilcox, Steve (1998) Owner occupation, employment and welfare: The impact of changing relationships on sustainable home ownership, Housing Studies, 13 (5), pp.623-638.

Froud, Julie, Leaver, Adam, Williams, Karel and Zhang, Wei (2007) The quiet panic about financial illiteracy, in: Libby Assassi, Anastasia Nesvetailova and Duncan Wigan (Eds) Global Finance in the New Century: Deregulation and Beyond (Basingstoke, Palgrave Macmillan). 
Gamble, Andrew (2008) Discussant: New Labour and an asset-holding society, Paper presented at the Political Studies Association annual conference, Swansea University, April 1-3 2008.

Giddens, Anthony (1991) The Consequences of Modernity(Cambridge, Polity).

HM Treasury (2000) Building Long-Term Prosperity For All: Pre-Budget Report (London, HMSO).

HM Treasury (2001a) Myners Review of Institutional Investment in the UK: Final Report (London, HMSO).

HM Treasury (2001b) Saving and Assets For All: The Modernisation of Britain's Tax and Benefit System, Number Eight (London, HMSO).

HM Treasury (2004) Barker Review of Housing Supply: Final Report Recommendations (London, HMSO).

HM Treasury (2006a) Pre-Budget Report 2006 (London, HMSO).

HM Treasury (2006b) Barker Review of Land Use Planning: Final Report Recommendations (London, HMSO).

HM Treasury (2007) Savings Gateway Scheme: Technical Report for the Second Pilot (London, HMSO).

Langley, Paul (2008) The Everyday Life of Global Finance: Saving and Borrowing in Anglo-America (Oxford, Oxford University Press).

Malpass, Peter (1996) The unravelling of housing policy in Britain, Housing Studies, 11 (3), pp.459-470.

Martin, Randy (2002) Financialization of Daily Life (Philadelphia, Temple University Press).

National Housing and Planning Advice Unit (2007) Affordability Matters (London, NHPAU). 
Royal Institution of Chartered Surveyors (2007) RICS Housing Accessibility and Affordability Update for Great Britain (London, RICS).

Schwartz, Herman and Seabrooke, Leonard (2008) Varieties of residential capitalism in the international political economy: Old welfare states and the new politics of housing, Comparative European Politics, 6 (3), 237-261..

Sherraden, Michael (2005) Assets and public policy, in: idem (Ed) Inclusion in the American Dream: Assets, Poverty, and Public Policy (Oxford: Oxford University Press).

Taylor, Jim and Bradley, Steve (1994) Spatial disparities in the impact of the 1990-92 recession: An analysis of UK counties, Oxford Bulletin of Economics and Statistics, 56 (4), pp.367-382.

Van Parijs, Philippe (1992) Arguing for Basic Income: Ethical Foundations for a Radical Reform (London, Verso).

Watson, Matthew (2008) Constituting monetary conservatives via the 'savings habit': New Labour and the British housing market bubble, Comparative European Politics, 6 (3), 285-304.

Wilding, Paul (1997) The welfare state and the Conservatives, Political Studies, 45 (5), pp.716-726. 